ISSN 1991- 8690

website : http:// jsci.utq.edu.iq
الترقيم الدولي 8690 - 2091

Email : utjsci@utq.edu.iq

\title{
Anti-inflammatory and antibacterial activities of Lippia nodiflora and its effect on blood clotting time
}

\author{
Ali Esmail Al-Snafi ${ }^{(1)}$ \\ Afrah Nasserallah Faris ${ }^{(2)}$ \\ ${ }^{(1)}$ Department of Pharmacology - College of Medicine \\ ${ }^{(2)}$ Departments of Biology - College of Science -Thi Qar University -Nasiriyah, Iraq.
}

\section{Abstract}

Aqueous extract of Lippia nodiflora possessed anti-inflammatory activity in Carrageenan induced mice paw edema in both doses 100 and $200 \mathrm{mg} / \mathrm{kg}$ bw $(\mathrm{P}<0.01)$. However, the ethanolic extracts didn't induced anti-inflammatory effects in both doses. Aqueous extract of Lippia nodiflora exerted a concentration dependent antibacterial activity against E.coli but not effective against Staphylococcus aureus and Pseudomonas aeruginosa. Ethanolic extract possessed antibacterial activity against gram positive (Staphylococcus aureus) and gram negative (E. coli) but not effective against Pseudomonas aeruginosa. Ethanolic extract of Lippia nodiflora significantly hasten blood clotting when used in a dose of $100 \mathrm{mg} / \mathrm{kg}(\mathrm{P}<$ $0.05)$ and $200 \mathrm{mg} / \mathrm{kg}(\mathrm{P}<0.01)$. The effect of the ethanolic extract appeared dose dependent. However, aqueous extract didn't exerted significant effects on blood clotting time in both doses used in this study.

Keywods: anti-inflammatory, antibacterial, Lippia nodiflora, clotting time, experimental

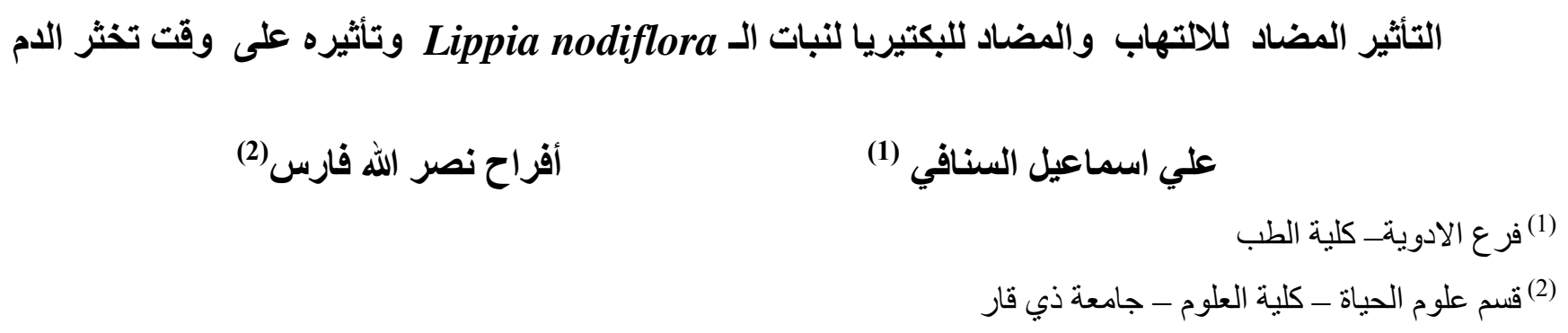

الخلاصة

كان للخلاصد المائيه لنبات Lippia nodiflora نأثيرا مضادا للالتهاب في الاستشقاء المحدث بالكاراجينان في اخص قدم الفئران عندما اعطيت بجرعة 100 و 200 ملغم / كغم من وزن الجسم (P>0.01). على اي حال لم تحدث خلاصنة الإيثانول تأثيرا مضادا

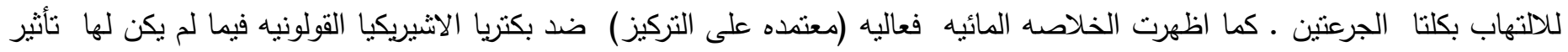

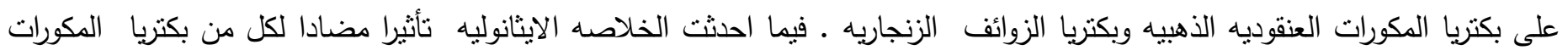


العنقوديه والاثيريكيا القولونيه ولم يكن لها تاثيرا على بكتربا الزوائف الزنجاريه ـ ان الخلاصه الكحوليه للنبات عجلت في تخثر الدم عندما استخدامها بجرعة 100 ملغم / كغم (P<0.05) و 200 ملغم / كغم من وزن الجسم (P) $(P 001)$ ـ فيما لم تحدث الخلاصه المائيه تأثيرا معنويا على وقت تخثر الدم في كلتا الجرعتين المستخدمه في الدراسه .

\section{Introduction}

Lippia nodiflora (Phyla nodiflora) is a small perenial herb belonging to the family verbenaceae. It was distributed all over the world particularly in Africa, sub-continent and most of the tropical and subtropical regions, particularly in maritime areas close to rivers ${ }^{(1)}$.

Lippia nodiflora contained triterpenoids, phenols (lippiflorin A and lippiflorin B, nepetin, batalilfolin , 6- hydroxyluteolin-7-Oapioside and luteolin-7-Oglucoside, flavones 6-hydroxyluteolin, Hispidulin 7-sulfate, hispidulin 7,4'-disulfate, jaceosidin 7,4'disulfate, nepetin 3',4'-disulfate ,nodifloretin 6,7disulfate, 6- hydroxyluteolin 6, 7-disulfate, nodifloretin 7-sulfate , 6-hydroxyluteolin 6-sulfate, 6-hydroxyluteolin 7- sulfate, jaceosidin 7-sulfate, nepetin 7-sulfate, and hispidulin 4'-sulfate), steroids, nodifloretin, $\beta$-sitosterol glycoside, stigmasterol glycoside, nodifloridin A and nodifloridin B , lactose, maltose, glucose, fructose, and xylose . Halleridone and Hallerone as their acetyl derivatives were also from the leaves of $L$. nodiflora $^{(2-7)}$.

L. nodiflora was reported to possess antiinflammatory, analgesic, antipyretic (8) antibacterial $^{(9-12)}$, antifungal ${ }^{(13-14)}$, larvicidal ${ }^{(15)}$, antitumor (16) , antidiuretic (17) , antidiabetic , hypolipidemic $^{(18)}$, and many other pharmacological effects. This study was designed to investigate the anti-inflammatory and antibacterial of Lippia nodiflora and its effect on clotting time.

\section{$\underline{\text { Materials and Methods }}$}

\section{Plant extraction:}

The plant leaves were purchased from local market, diagnosed, dried, and powdered using pestle and mortar. Then $200 \mathrm{~g}$ of the ground leaves were divided into two equal portions and subjected to exhaustive soxhlet extraction in ethanol or distilled water $(500 \mathrm{ml}$ each $)$ for $72 \mathrm{~h}$ at $60{ }^{\circ} \mathrm{C}$. Then the extracts were dried under vacuum ${ }^{(19)}$.

\section{Experimental animals:}

Sixteen Adult albino mice (weighing 25- $30 \mathrm{~g}$ ) were used in this study. All the animals were housed in a cross ventilated room (temperature 22 $\pm 2^{0} \mathrm{C}, 12 \mathrm{~h}$ light/ $12 \mathrm{~h}$ dark cycle) and standard diet and water were given ad libitum.

\section{Anti-inflammatory test:}

Anti-inflammatory activity was assessed in mice on the basis of the inhibition of the Carrageenan induced hind paw oedema. Thirteen mice were divided into five experimental groups (6 animals each) and the basal thickness of the right hind paw was determined before the administration of any drug. Extracts (100, 200 $\mathrm{mg} / \mathrm{kg}$ ), and vehicle control were orally administered $1 \mathrm{hr}$ prior the Carrageenen administration. Acute inflammation was produced by the subplanter administration of $0.05 \mathrm{ml}$ of $1 \%$ Carrageenan suspension in $0.9 \% \mathrm{NaCl}$ in the right hind paw of the mice. The volume at the oedema was monitored by measuring the thickness at hind paw swelling $1 \mathrm{hr}$ after Carrageenan injection by using vernier caliper. The results are presented as the paw thickness variation in relation to the basal values ${ }^{(19-20)}$.

\section{Antibacterial test:}

In vitro antibacterial effects was carried out on clinical isolates, Gram positive (Staphylococcus aureus) and Gram negative (Echerichia coli and Pseudomonas aeruginosa). The cultures of these bacteria were checked for purity by doing gram staining and biochemical test ${ }^{(\mathbf{1 9})}$, and they were grown in nutrient broth at $37^{\circ} \mathrm{C}$ and maintained in nutrient agar slants at $2-8^{\circ} \mathrm{C}$.Nutrient agar medium 
was used as bacterial culture medium in the antibacterial assays ${ }^{(21)}$.

\section{Clotting time test:}

Thirteen mice were divided in five groups ( 6 mice each). The first group was given the vehicle to serve as control. The rest four groups were given the aqueous and ethanolic extracts of Lippia nodiflora, each extract in two dose level (100 and $200 \mathrm{mg} / \mathrm{kg} \mathrm{bw}$ ) orally. one hour later, the time required for clotting of a drop of blood taken on slide by tail venipuncture was estimated according to the previous methods $(19,22)$.

\section{Results}

Aqueous extract of Lippia nodiflora possessed anti-inflammatory activity in Carrageenan induced mice paw edema in both doses 100 and $200 \mathrm{mg} / \mathrm{kg}$ bw $(\mathrm{P}<0.01)$. However, the ethanolic extracts didn't induced anti-inflammatory effects in both doses (table 1).

Aqueous extract of Lippia nodiflora exerted a concentration - dependent antibacterial activity against E.coli but not against Staphylococcus aureus and Pseudomonas aeruginosa. Ethanolic extract possessed antibacterial activity against both gram positive (Staphylococcus aureus) and gram negative (E. coli) but not against Pseudomonas aeruginosa (table 2 ).

Ethanolic extract of Lippia nodiflora significantly hasten blood clotting when used in a dose of 100 $\mathrm{mg} / \mathrm{kg}(\mathrm{P}<0.05)$ and $200 \mathrm{mg} / \mathrm{kg}(\mathrm{P}<0.01)$. The effect of the ethanolic extract appeared dose dependent. However, aqueous extract didn't exerted significant effects on blood clotting time in both doses used in this study (table 3).

Table 1: The anti-inflammatory effects of aqueous and ethanolic extracts of Lippia nodiflora in Carrageenan induced mice paw edema $(\mathrm{mm})$.

\begin{tabular}{|c|c|c|c|c|c|}
\hline \multicolumn{1}{|c|}{ Groups } & $\begin{array}{c}\text { Thickness of } \\
\text { right paw } \\
\text { before } \\
\text { administration } \\
\text { of } \\
\text { Carrageenan } \\
(\mathrm{mm})\end{array}$ & $\begin{array}{c}\text { Thickness of } \\
\text { right paw after } \\
\text { administration of } \\
\text { Carrageenan(mm) }\end{array}$ & $\begin{array}{c}\text { The variations in } \\
\text { the hickness of the } \\
\text { paw between } \\
\text { before } \\
\text { and after } \\
\text { administration of } \\
\text { Carrageenan }(\mathrm{mm})\end{array}$ & $\begin{array}{c}\text { Level of } \\
\text { significancy in } \\
\text { comparison } \\
\text { with } \\
\text { control group }\end{array}$ \\
\hline \multicolumn{2}{|c|}{ Control } & $1.7 \pm 0.45$ & $2.83 \pm 0.15$ & $1.2 \pm 0.21$ & \\
\hline \multirow{2}{*}{$\begin{array}{c}\text { Aqueous } \\
\text { Extract }\end{array}$} & $100 \mathrm{mg} / \mathrm{kg} \mathrm{bw}$ & $2.12 \pm 0.22$ & $2.90 \pm 0.33$ & $0.75 \pm 0.23$ & $\mathrm{P}<0.01$ \\
\cline { 2 - 6 } & $200 \mathrm{mg} / \mathrm{kg} \mathrm{bw}$ & $1.64 \pm 0.32$ & $2.22 \pm 0.35$ & $0.58 \pm 0.13$ & $\mathrm{P}<0.01$ \\
\hline Ethanolic & $100 \mathrm{mg} / \mathrm{kg} \mathrm{bw}$ & $2.00 \pm 0.45$ & $2.96 \pm 0.20$ & $0.97 \pm 0.28$ & $\mathrm{NS}$ \\
\cline { 2 - 6 } Extract & $200 \mathrm{mg} / \mathrm{kg} \mathrm{bw}$ & $2.06 \pm 0.41$ & $3.03 \pm 0.25$ & $0.97 \pm 0.20$ & $\mathrm{NS}$ \\
\hline
\end{tabular}


Table 2: The means of diameters of the zones of growth inhibition (mm) of 4 and $8 \mathrm{mg}$ of aqueous and ethanolic extracts of Lippia nodiflora

\begin{tabular}{|l|c|c|c|c|}
\hline \multirow{2}{*}{ Type of bacteria } & \multicolumn{4}{|c|}{$\begin{array}{c}\text { Diameters of the zones of growth } \\
\text { inhibition (mm) }\end{array}$} \\
\cline { 2 - 5 } & Aqueous extract & \multicolumn{2}{|c|}{ Ethanolic extract } \\
\cline { 2 - 5 } & $4 \mathrm{mg}$ & $8 \mathrm{mg}$ & $4 \mathrm{mg}$ & $8 \mathrm{mg}$ \\
\hline Staphylococcus aureus & $-\mathrm{ve}$ & $-\mathrm{ve}$ & 4 & 8 \\
\hline E. coli & 10 & 14 & 5 & 5 \\
\hline Pseudomonas aeruginosa & -ve & -ve & $-\mathrm{ve}$ & -ve \\
\hline
\end{tabular}

Table 3: Effects of aqueous and ethanolic extracts of Lippia nodiflora on bleeding time in mice

\begin{tabular}{|l|l|l|c|}
\hline \multicolumn{2}{|l|}{ Groups } & Bleeding time & $\begin{array}{c}\text { Level of significancy } \\
\text { in comparison with control }\end{array}$ \\
\hline Control & $87.0 \pm 31.0$ & \\
\hline Aqueous extract & $100 \mathrm{mg} / \mathrm{kg} \mathrm{bw}$ & $104.0 \pm 13.5$ & $\mathrm{NS}$ \\
\cline { 2 - 4 } & $200 \mathrm{mg} / \mathrm{kg}$ bw & $85.6 \pm 4.0$ & $\mathrm{NS}$ \\
\hline Ethanolic extract & $100 \mathrm{mg} / \mathrm{kg}$ bw & $66.0 \pm 5.9$ & $\mathrm{P}<0.05$ \\
\cline { 2 - 4 } & $200 \mathrm{mg} / \mathrm{kg}$ bw & $52.0 \pm 6.4$ & $\mathrm{P}<0.01$ \\
\hline
\end{tabular}

\section{Discussion}

Plants are a main source of a wide range of secondary metabolites, which are used as pharmaceuticals, agrochemicals, flavours, fragrances, colours, biopesticides and food additives. Medicinal plants are the Nature's gift to human beings to help them pursue a disease-free healthy life. Plants have been used as drugs by humans since thousands of years ago ${ }^{(1)}$.

From our results, the aqueous extract of Lippia nodiflora exerted anti-iniflammatory effects in Carrageenan induced mice paw edema. These results were in agreement with the results recorded by Ahmad et al ${ }^{(23)}$.

Oedema formation in the paw was occurred as a result of synergism between various inflammatory mediators that increase vascular permeability and the mediators that increase blood flow ${ }^{(24)}$. Although, inflammatory response can be induced by several experimental models of paw oedema , but Carrageenan-induced paw oedema is widely used for determining the acute phase of inflamemation. Histamine, 5-hydroxytryptamine and bradykinin were the first detectable mediators in the early phase of carrageenan-induced inflammation and prostaglandins were the mediators of the late phase of inflammation ${ }^{(25-26)}$. According to our results, it appeared that the aqueous extract of Lippia nodiflora the mediators of early phase of inflammation.

Antibacterial activities of the methanolic extracts from the leaves and flowers of Lippia nodiflora L. (Verbenaceae), were studied by Zare et al The extracts showed antimicrobial impact on bacteria such as Bacillus subtilis, B. cereus, Micrococcus luteus, Staphylococcus aureus, Pseudomonas aeruginosa, Klebsiella pneumonia, K. oxytoca and Esherichia coli. Our results showed 
that increasing concentrations of extracts increased the antibacterial activities in all of the microorganisms. Bacteria were more sensitive than fungi, and gram positive bacteria were more sensitive than gram negative ones ${ }^{(27)}$.

This study in part in agreement with other results which investigate the antibacterial and antiinflammatory effects of Lippia nodiflora ${ }^{(8-12)}$, but our results showed that the alcoholic extract was more potent in Gram negative, these could be attributed to different types of extractive materials and different types of solvents. Zare et al extracted leaves and flowers by methanol while we extracted the leaves only by ethanol. The antibacterial activity may be due to alkaloids, flavonoids, tannin and oils of Lippia nodiflora, the same constituents when isolated from other plants showed antibacterial activity ${ }^{(28-29)}$.

The study of Ahmad et al recorded that the significant anti-inflammatory activity of the Lippia nodiflora extracts was observed in the first phase of carrageenin induced inflammation They suggested that this effect attributed to inhibition of early mediators, such as histamine and serotonin . Its effects on the second stage of inflammation was less ${ }^{(23)}$, which give an indication that it has no strong effect on prostaglandins. Prostaglandins especially thromboxane A2 are the mediators which induced platelets aggregation and subsequent clotting. This could be explain the inhibitory effects of Lippia nodiflora on the clotting process and the prolongation of clotting time.

According to these results, It can be concluded that Lippia nodiflora exerted anti-inflammatory and antibacterial effects as well as, it enhanced clotting process and decreased blood clotting time.

\section{References}

1-Amir F, Yam WS and Chin KY. Chemical constituents and biological applications of Lippia nodiflora. Archives of Pharmacy Practice 2011; 2(3): 101-105.

2-Joshi BC. Chemical examination of Lippia nodiflora Vijnana Parishad Anusandhan Patrika, 1970; 11(4): 214-219.
3-Nair AGR, Ramesh P, Nagarjan $S$ and Subraimanam S. A new flavones glycosides from Lippia nodiflora. Indian Journal Chem 1973; 2:1316-1317.

4-Barnabas C, Gunasingh G, and Nagarajan S, Flavonoids from the flowers of Phyla nodiflora Linn. Indian Journal of Chemistry, Section B: Organic Chemistry including Medicinal Chemistry1980; 19B(9): 822.

5-Khalil AT, Lahloub MF and Salama OM. Phenolic compounds from Lippia nodiflora. Journal of Pharmaceutical Sciences 1995; 11(2): 256-265.

6-Tomas-Barberan FA, Harborne JB and Self R. Twelve 6-oxygenated flavone sulphates from Lippia nodiflora and L.canescens, Phytochemistry 1987; 26(8) : 2281-2284.

7-Ravikanth V,Ramesh P, Diwan PV and Venkateswarlu Y. Halleridone and Hallerone from Phyla nodiflora as taxonomic markers. Biochemical Systematic and Ecology 2000; 28(9):905-906.

8-Forestieri AM, Monforte MT, Ragusa S, Trovato A, Iauk L. Anti-inflammatory, analgesic and antipyretic activity in rodents of plant extracts used in African Medicine. Phytother Res 1996; 10: 100-106.

9- Malathi R, Cholarajan A, Karpagam K, Jaya $\mathrm{KR}$, and Muthukumaran $\mathrm{P}$ Antimicrobial studies on selected medicinal plant Coleus amboinious, Phyla nodiflora and Vitex negundo. Asian J PharmaTech 2011; I (2):53-55.

10-Ravikumar VR and Sudha T, Phytochemical and microbiological observations on Phyla nodiflora. Int $\mathrm{J}$ of Res in Pharmacy and Chemistry 2011; 1(2): 117-120.

11-Bhakuni DS, Dhar ML, Dhar MM, Dhawan BN. and Mehlotra BN. Screening of Indian plants for biological activity. Part II. Indian J of Exp Bio 1969, 7.250.

12-Patel Janki B, Shah Kinjal $H$ and Patel Rashmika C. Evaluation of anti bacterial activity of methanolic extract of seeds of Phyla nodiflora Linn. Int Research Journal of Pharmacy 2011; 2(6): 91-93. 
13-Pirzada AJ, Iqbal P, Shaikh W, Kazi T G and Ghani KV. Studies on elemental composition and antifungal activity of medicinal plant $L$. nodiflora against skin fungi. Journal of Pak Assoc Derma 2005; 15(2): 113-118.

14-Pascual ME, Slowing K, Carreto E, Sanchez mata D and Villar A. Lippia: traditional uses,chemistry and pharmacology - a review. $\mathrm{J}$ of Ethnopharmacology2001;76(3): 201214.

15-Zheng L. Application of Lippia nodiflora extract to preparing medicinal preparation for treating hepatitis. China patent 2008; 2(3): 101-105.

16-Durairaj AK, Mazumdar UK, Gupta M and Selvan VT. Effect on inhibition of proliferation and antioxidant enzyme level of Lippia nodiflora in EAC cell line treated mice. Journal of Complementary and Integrative Medicine 2009; 6(1): 713-714.

17-Shukla S, Patel R and Kukkal R. Study of phytochemical and diuretic potential of methanol and aqueous extract of aerial parts of Phyla nodiflora Linn. Int Journal of Pharma and Pharm Sciences 2009; 1 (1): 8591.

18-Balamurupan R, Duraipandiya V and Savarimuthu IG. Antidiabetic activity of YSitosterol isolated from Lippia Nodiflora $L$. in streptozotocin induced diabetic rats." European Journal of pharmacology2011; 667 (1-3) : 410-418.

19-Ghosh MN. Fundamentals of experimental pharmacology, $3^{\text {rd }}$ ed. Hilton and Co , Kolkata 2005.

20- Paschapur MS, Patil MB, Kumar R and Patil SR. Evaluation of anti-inflammatory activity of ethanolic extract of Borassus flabellifer L. male flowers (inflorescences) in experimental animals. Journal of Medicinal Plants Research 2009; 3(2) :49-54.

21-Dhale AD. Phytochemical screening and antimicrobial activity of Bauhinia variegata Linn. Journal of Ecobiotechnology 2011; 3(9):4-7.
22- Garcia-Manzano A, Gonzaleze-Llaven J, Lemni $\mathrm{C}$ and Rubio-Poo C. Standardization of rat blood clotting tests with reagents used for human .Proc West Pharmacol Soc 2001, 44: 153-155.

23- Ahmed F, Selim MST, Das AK and Choudhuri MSK. Anti-inflammatory and antinociceptive activities of Lippia nodiflora Linn. Pharmazie 2004;59(4):329-330.

24-Ialenti A, Ianaro A, Moncada S and Di Rosa M - Modulation of acute inflammation by endogenous nitric oxide. Eur J Pharmacol 1995; 211:177-184.

25-Di Rosa M and Willoughby DA. Screens for anti-inflammatory drugs. J Pharm Pharmacol 1971; 23: 297-303.

26-Salvemini D, Wang ZQ, Bourdon DM, Stern MK, Currie MG and Manning PT. Evidence of peroxynitrite involvement in the carrageenaninduced rat paw edema Eur J Pharmacol 1996; 303: 217-224.

27-Zare Z, Majd A, Sattari TN, Iranbakhsh A and Mehrabian S.Antimicrobial activity of the leaf and flower extracts of Lippia nodiflora L.(verbenacea). Journal of Plant Protection Res 2012 ; 52(4): 401-403.

28-Irobi ON, Moo-young M, Anderson WA and Daramola SO Antimicrobial activity of bark extracts of Bridelia feraginea. $\mathrm{J}$ Ethnofarmacol 1994; 43 (3): 185-190.

29-Brantner A, Males A, Pepeljak S and Antolic A. Antibacterial activity of Paliurus spinaChrist Mill (Christis thorn). J Ethnopharmacol 1996; 52 (2): 119-122. 